\title{
オキソアンモニウム塩の設計に基づく有用酸化反応システムの開発研究
}

\author{
涉谷正 俊†
}

\section{Development of Versatile Oxidation Systems Based on the Design of Oxoammonium Salts}

\author{
Masatoshi Shibuya ${ }^{\dagger}$ \\ Graduate School of Pharmaceutical Sciences, Tohoku University; \\ 6-3 Aoba, Aramaki, Sendai 980-8578, Japan.
}

(Received May 31, 2012)

\begin{abstract}
Organic nitroxyl radical catalysts have recently attracted great attention because they realize efficient alcohol oxidation under mild and environmentally benign conditions. A representative of this class is 2,2,6,6-tetramethylpiperidine 1oxyl (TEMPO) . We have also developed 2-azaadamantane $N$-oxyls (AZADOs) as highly efficient oxidation catalysts. These nitroxyl radicals are generally oxidized by a cooxidant to generate oxoammonium salts, which are active species for alcohol oxidation. In the oxidation systems presented in this paper, we focus on the differences between these two species in terms of oxidation state and counter anion. Herein, the effects of a counter anion of an oxoammonium species on its reaction selectivity are shown. On the basis of the control of the counter anion, we have developed catalytic oxidative rearrangement of tertiary allylic alcohols to $\beta$-substituted $\alpha, \beta$-unsaturated carbonyl compounds. Moreover, we have developed novel useful oxidation systems utilizing a catalytic oxoammonium salt; namely, a one-pot oxidation of primary alcohols to carboxylic acids and an aerobic alcohol oxidation.
\end{abstract}

Key words _ organocatalyst; alcohol oxidation; oxidative rearrangement; nitroxyl radical; oxoammonium salt

\section{1. はじめに}

創薬研究においては，多様な構造を持つ目的化合 物を迅速かつ高選択的に化学合成する技術が求めら れる．近年の有機合成化学の目覚ましい発展によっ て, 多種多様な有機反応が開発され，複雑な構造を 有する生物活性天然物の全合成も次々を報告される ようになってきた。このような現代においては, 目 的の変換反応を簡単に, そして短時間に達成できる 反応は魅力的である.さらに，実際の使用を考えた 場合に重要となるのは, その反応が適用性の広い信 頼度の高い反応であるということである.

アルコールからカルボニル化合物への酸化反応に は，数多くの反応が開発されているが，その多く

The author declares no conflict of interest.

東北大学大学院薬学研究科（T980-8578 仙台市青葉区 荒巻字青葉 6-3)

現所属: ‘名古屋大学大学院創薬科学研究科（下4648601 名古屋市千種区不老町)

e-mail: m-shibu@ps.nagoya-u.ac.jp

本総説は, 平成 23 年度日本薬学会東北支部奨励賞の受

賞を記念して記述したものである.
が，毒性や爆発性の酸化剂を用いるなど，いまだ改 善の余地を有している，筆者は，毒性試薬を用い ず，かつ，廃棄物の少ない環境調和条件下に，「ど んな基質においても進行する切れ味のよいアルコー ル酸化反応」の開発を目指し研究を行ってきた. 100\%いかなる基質にも収率よく目的の反応を進行 させることは極めて困難であるが, 官能基共存性と 基質適用性に優れたいくつかの反応開発に成功した ので,ここで紹介したい.

筆者らは，これまで有機ニトロキシルラジカル 2,2,6,6-tetramethylpiperidine 1-oxyl (TEMPO) (1) を触媒とする酸化反応が，工業プロセスへも適用可 能な数少ないアルコール酸化反応であることに着目 して研究を行い, ${ }^{1-4)}$ TEMPO 酸化の適用が難しい 立体的に混夕合った第 2 級アルコールの酸化も速や かに進行する高活性有機ニトロキシルラジカル 2azaadamantane $N$-oxyl（AZADO）（2）の開発に成 功している (Fig. 1).5) ニトロキシルラジカルは, 通常 $\alpha$ 位に水素原子を持つ場合には, ニトロンと ヒドロキシルアミンへの不均化反応が速やかに進行 
するために安定に存在することはできない。したが つて, TEMPO（1）の 4 つのメチル基は, 安定に存 在するための必須の構造単位である. ${ }^{6,7)}$ これに対し AZADO（2）は，ニトロキシルラジカル $\alpha$ 位の水 素原子がアザアダマンタン核の橋頭位に位置するた めに安定に存在できる. ${ }^{5,8)}$ そのため, 触媒活性部位 周辺に広い反応場が確保でき，立体的に混み合った 第 2 級アルコールとも速やかに反応する. 9,10)

TEMPO（1） 及び AZADOs（2, 3) を始めとす る有機ニトロキシルラジカル型酸化触媒は，多くの 場合，系中で酸化されて発生するオキソアンモニウ 厶塩を酸化活性種として反応が進行すると考えられ ている. ${ }^{11-14)}$ ここで，ニトロキシルラジカルとオキ ソアンモニウム塩には, 酸化段階の違いに加えカウ ンターアニオンの有無という違いがある (Fig. 2). 有機ニトロキシルラジカルを用いる触媒的酸化反応 システムにおいては，ブラックボックスに入ってし まうためか, この 2 点の違いに着目した研究はほと んどなされてこなかった。筆者は，これまで注意が 払われてこなかったこの違いを利用すると，ここで 紹介する有用酸化反応システムが開発できることを 見い出した。

\section{2. オキソアンモニウム塩を用いる酸化的転位反} 応 15

第 3 級アリルアルコールの $\beta$ 置換- $\alpha, \beta$-不飽和カ ルボニル化合物は，有機金属試薬による 1,2-付加反 応と組み合わせることで“1,3-alkylative carbonyl transposition”を可能にすることから，有機合成化 学上重要な反応である (Scheme 1)。1970 年代後半 に，Babler, Dauben, Herz らによって PCC 及び

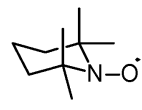

TEMPO (1)

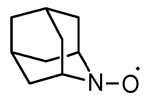

AZADO (2)

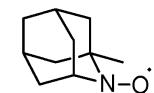

1-Me-AZADO (3)

Fig. 1. Structures of Nitroxyl Radicals

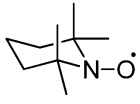

TEMPO (1)

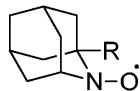

$\mathrm{R}=\mathrm{H} \quad A Z A D O(2)$ $\mathrm{R}=\mathrm{Me}$ 1-Me-AZADO (3)
PDC の本反応に対する有用性が示されて以来，有 機合成においては専ら毒性の高い 6 価のクロム酸を

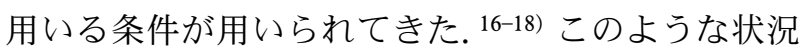
において筆者らは，環境調和条件下に第 3 級アリル アルコールの酸化的転位反応を進行させる条件を探 索した。その結果，5価超原子価ヨウ素試薬 IBX が 5,6 員環上の第 3 級アリルアルコールの酸化的転 位反応を進行させることを見い出し，2004 年に報 告した. ${ }^{19)}$ 酸化的転位反応の更なる効率化のため, 触媒的手法とより基質適用性に優れた手法の開発を 目指し，次に筆者らはオキソアンモニウム塩に着目 し研究を続けた。 オキソアンモニウム $\left(\mathrm{R}_{1} \mathrm{R}_{2} \mathrm{~N}^{+}=\right.$ O）は，クロム酸の $\mathrm{Cr}=\mathrm{O}$ や $\mathrm{IBX} の \mathrm{I}=\mathrm{O}$ と構造 的に類似していることから (Fig. 3)，ニトロキシ ルラジカルあるいはオキソアンモニウム塩を用いる 条件でも酸化的転位反応が進行するものと期待して 検討を開始した。

はじめに触媒量の TEMPO（1）と種々の共酸化 剂を用いて検討を行ったが，効率的に酸化的転位反 応を進行させる条件を見い出すことはできなかっ

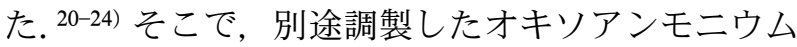
塩を化学量論量用いて検討を行うこととした。 ${ }^{25-29)}$ その結果, $\mathrm{Cl}^{-}, \mathrm{Br}_{3}^{-}$のカウンターアニオンを持つ オキソアンモニウム塩 $\left(\mathrm{TEMPO}^{+} \mathrm{X}^{-}\right)(\mathbf{4 a}, \mathbf{4 b})$ は,

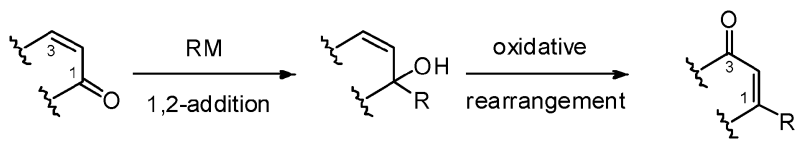

Scheme 1. 1,3-Alkylative Carbonyl Transposition

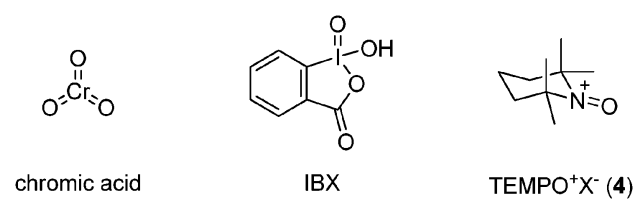

Fig. 3. Structural Homology of Chromic Acid, IBX, and Oxoammonium Species

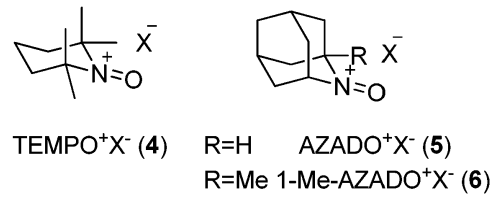

Fig. 2. Structural Comparison of Oxoammonium Salts with Nitroxyl Radicals 
目的の酸化的転位反応成績体は得られなかつたが, その一方で， $\mathrm{BF}_{4}^{-}$をカウンターアニオンに持つ $\mathrm{TEMPO}^{+} \mathrm{BF}_{4}^{-}(\mathbf{4 c})$ を用いた場合には，室温下 3 分 以内と極めて短時間で反応が完結し高収率で目的の 酸化的転位反応成績体を与えることを見い出した (Scheme 2)。 そこで, $\mathrm{TEMPO}^{+} \mathrm{BF}_{4}^{-}$(4c) 1.5 当量 を用いた条件下，基質適用性を検討した（Table 1)。その結果，5,6 員環 3 級アリルアルコール基質 のみならず，IBX を用いる条件では適用ができな かった中員環基質，マクロ環基質や鎖状基質におい ても高収率で反応が進行した。ここで，アセトニト<smiles>OC1(c2ccccc2)C=CCCC1</smiles>

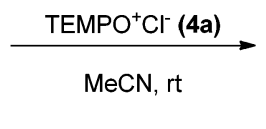

$7 a$<smiles>OC1(c2ccccc2)C=CCCC1</smiles>

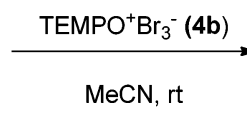

$7 a$<smiles>OC1(c2ccccc2)C=CCCC1</smiles><smiles>COC(C)(C)[Ge]</smiles>

$7 a$

Scheme 2. Reaction of $\mathrm{TEMPO}^{+} \mathrm{X}^{-}$ Alcohols complex mixture<smiles>BrC1CCCC(Br)(c2ccccc2)C1Br</smiles>

$8(100 \%)$<smiles>O=C1C=C(c2ccccc2)CCC1</smiles>

$7 b(95 \%)$

Table 1. Scope of Oxoammnonium-salt-mediated Oxidative Rearrangement

\begin{tabular}{llll} 
Yield/Time \\
\hline
\end{tabular}

Method A: TEMPO ${ }^{+} \mathrm{X}^{-}(1.5 \mathrm{eq}), \mathrm{MeCN}, \mathrm{rt}$; Method B: $\mathrm{TEMPO}^{+} \mathrm{X}^{-}(1.5 \mathrm{eq}), \mathrm{MeCN}: \mathrm{H}_{2} \mathrm{O}(1: 1)$. ${ }^{\text {a }}$ Reaction perfomed at $40^{\circ} \mathrm{C}$, b Reaction perfomed at $50^{\circ} \mathrm{C}$.<smiles></smiles> 
リルのみを溶媒とした場合に，7員環基質で，二量 体 11c の生成がわずかながらみられた。そこで，こ の副反応を回避するため, 中員環基質とマクロ環基 質ではアセトニトリルと水の混合溶媒を用いた。 三 置換オレフィンを持つ基質 18a では，オレフィン部 との反応が優先した生成物 $\mathbf{1 8 d}$ が得られた. ${ }^{30)}$

ハロゲン化物イオンをカウンターアニオンとする $\mathrm{TEMPO}^{+} \mathrm{Cl}^{-}(\mathbf{4 a}), \mathrm{TEMPO}^{+} \mathrm{Br}_{3}^{-}$(4) $)$では全く目 的の反応が進行せず， $\mathrm{TEMPO}^{+} \mathrm{BF}_{4}^{-}(\mathbf{4 c})$ では効 率的に酸化的転位反応が進行することから，カウン ターアニオンの反応性に与える影響について，さら に 5 種のカウンターアニオンを持つ $\mathrm{TEMPO}^{+} \mathrm{X}^{-}$ （4）を調製し，16a を基質として酸化的転位反応を 検討した（Table 2)。その結果，その差は顕著では ないものの $\mathrm{BF}_{4}^{-}, \mathrm{NTf}_{2}^{-}, \mathrm{OTf}^{-}$をカウンターアニオ ンに持つ $\mathrm{TEMPO}^{+}$に比べ, $\mathrm{ClO}_{4}^{-}, \mathrm{PF}_{6}^{-}, \mathrm{SbF}_{6}^{-}$を カウンターアニオンに持つ $\mathrm{TEMPO}^{+}$がより効率的 に酸化的転位反応を進行させた。そこで， $\mathrm{TEMPO}^{+} \mathrm{SbF}_{6}^{-}$（4h）をマクロ環基質や鎖状基質に 適用したところ，目的の成績体の収率が向上した (Table 1).

転位を伴わない通常の第 1,2 級アルコールの酸化 反応では, ハロゲン化物イオンを持つ $\mathrm{TEMPO}^{+} \mathrm{Cl}^{-}$ (4a) や $\mathrm{TEMPO}^{+} \mathrm{Br}_{3}^{-}$(4b) が $\mathrm{TEMPO}^{+} \mathrm{BF}_{4}^{-}$(4c) に比べ効率的に進行させるという予備的知見を得て いたことから，オキソアンモニウム塩のカウンター アニオンの違いによる反応性の差について分子間競
合実験によって評価した（Scheme 3）。その結果， 興味深い反応性が明らかとなった。すなわち，ベン ジルアルコール 19a と第 3 級アリルアルコール 9a を共存させ， $\mathrm{TEMPO}^{+} \mathrm{Cl}^{-}$(4a) を添加した場合 には，ベンジルアルコール 19a の酸化が優先して進 行した。これに対し， $\mathrm{TEMPO}^{+} \mathrm{BF}_{4}^{-}(\mathbf{4 c})$ を用い た場合には，第 3 級アリルアルコール 9a の酸化的 転位反応がベンジルアルコール 19a の酸化に対し優 先して進行した。ささらに, $\mathrm{TEMPO}^{+} \mathrm{Cl}^{-}$(4a) と $\mathrm{AgBF}_{4}$ から系中で $\mathrm{TEMPO}^{+} \mathrm{BF}_{4}^{-}$（4c) を調製した 場合にも，第 3 級アリルアルコール 9a の酸化的転 位反応が優先して進行した.

筆者は，このカウンターアニオンの反応性の差に ついて， $\mathrm{TEMPO}^{+} \mathrm{BF}_{4}^{-}(\mathbf{9 c})$ のカウンターアニオ ンの共役酸である $\mathrm{HBF}_{4}$ が超強酸（ $\left.K_{\mathrm{a}}=-4.9,{ }^{31}\right)$ 1.8 (in $\mathrm{MeCN}$ (predicted) $\left.{ }^{32)}\right)$ であることから，以

Table 2. Reactivity of Series of TEMPO ${ }^{+} \mathrm{X}^{-}(\mathbf{4})$

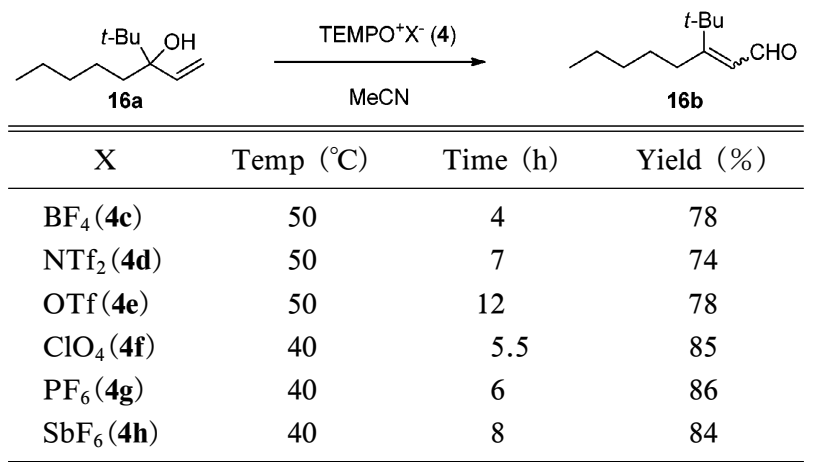

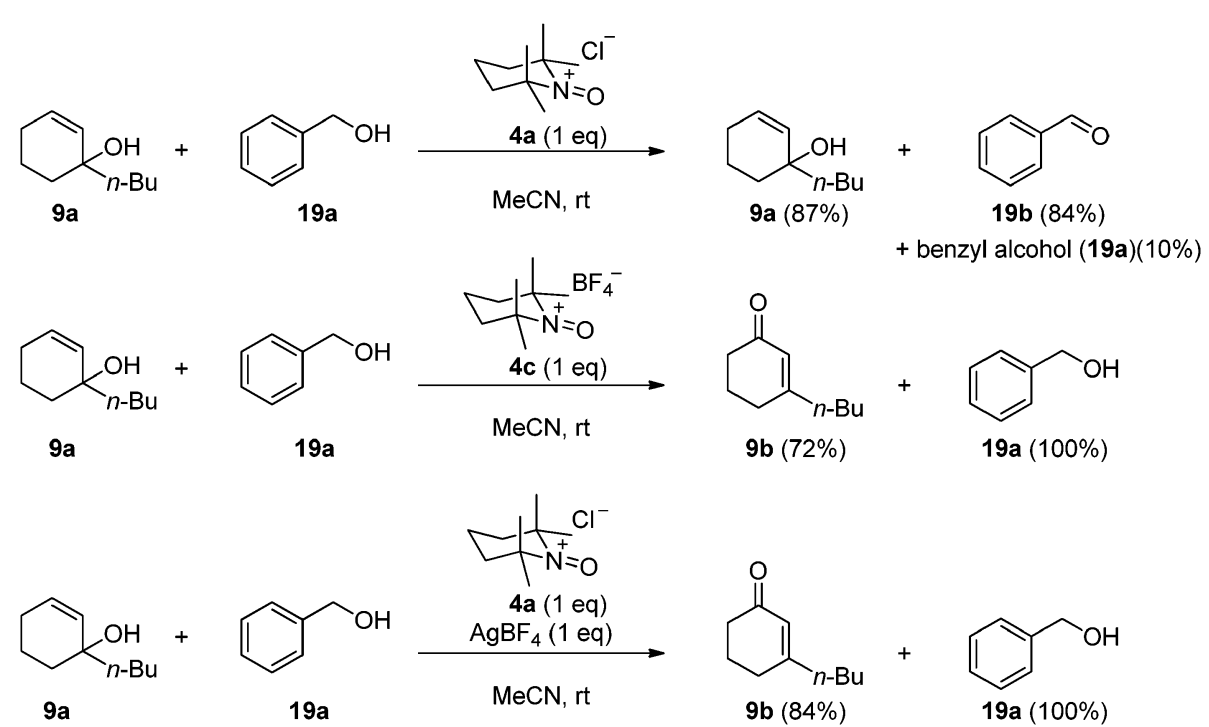

Scheme 3. Intermolecular Competitive Experiments 
a Oxidation of Benzyl Alcohol

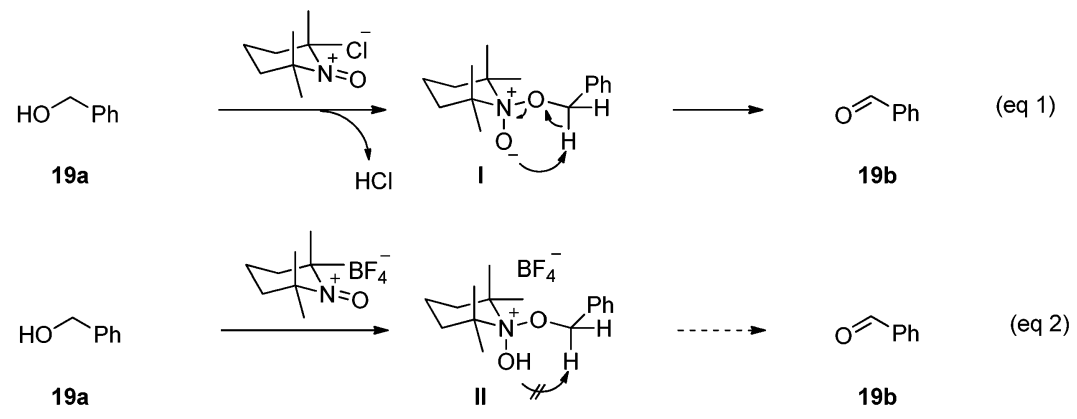

b Oxidative Rearrangement of Tertiary Allylic Alcohol
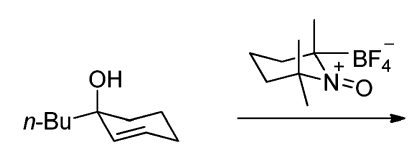

$9 a$

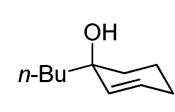

$9 a$

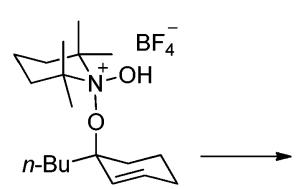

III

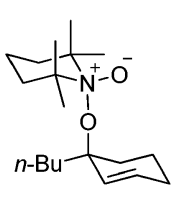

V

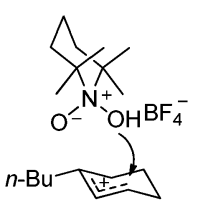

IV
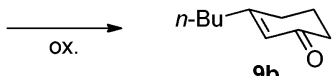

(eq 3)

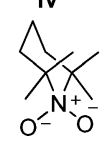

$n-\mathrm{Bu}+\mathrm{P}$

VI

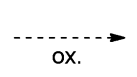

$n-\mathrm{Bu}$

9b

Scheme 4. Proposed Reaction Pathway for Oxidation and Oxidative Rearrangement

下のように説明できると考えている (Scheme 4). ${ }^{33)}$ すなわち， $\mathrm{TEMPO}^{+} \mathrm{Cl}^{-}(\mathbf{4 a})$ によるベンジルア ルコール 19a の酸化は，Eq. 1 のように進行すると 考えられる. ${ }^{11-14)} \mathrm{TEMPO}^{+} \mathrm{BF}_{4}^{-}$(4c) を用いた場合 には， $\mathrm{HBF}_{4}$ が超強酸のためにプロトン化を受けた 中間体 II が安定化され，次の酸化反応の進行が抑 制される（Eq. 2)。また，第 3 級アリルアルコール 酸化的転位反応では， $\mathrm{TEMPO}^{+} \mathrm{BF}_{4}^{-}(\mathbf{4 c})$ を用い た場合には，オキソアンモニウム部に第 3 級アリル アルコール 9a が付加した後, TEMPO とアルコー ル周辺の嵩高さによってイリドが一度脱離しアリル カチオン（IV）を生じる。 その後, 立体障害の小 さい 3 位に付加し酸化が進行することで成績体 9b を与える (Eq. 3)。これに対し， $\mathrm{TEMPO}^{+} \mathrm{Cl}^{-}(\mathbf{4 b})$ は，小さな $\mathrm{Cl}^{-}$が $\mathrm{BF}_{4}^{-}$に比べ，オキソアンモニウ 厶塩の窒素原子近傍で静電的に安定化しているため に立体障害の大きな第 3 級アリルアルコール 9a の 付加が進行しないか, あるいは, 付加の際に $\mathrm{HCl}$ が脱離し中間体 $\mathbf{V}$ が安定化されるために次の脱離 が進行しない（Eq. 4)。以上のようなメカニズムに よって, カウンターアニオンがオキソアンモニウム
種の反応選択性の決定に重要な役割を果たしている ものと考察している.

\section{3. 触媒的酸化的転位反応の開発 ${ }^{34)}$}

上記の化学量論量のオキソアンモニウム塩を用い た検討から，筆者は，オキソアンモニウムのカウン ターアニオンがその反応性に大きな影響を与えるこ とを強く認識した。 そこで, 系中で発生するオキソ アンモニウム塩のカウンターアニオンを制御するこ とができれば，触媒的な酸化的転位反応の開発がで きると考えた。はじめに， $\mathrm{TEMPO}^{+} \mathrm{BF}_{4}^{-}(\mathbf{4 c})$ を 触媒として用いることによって，系中で再び生成す るオキソアンモニウム塩が $\mathrm{TEMPO}^{+} \mathrm{BF}_{4}^{-}(\mathbf{4 c})$ と なることを期待し検討した。 その結果，共酸化剂と して $\mathrm{PhI}(\mathrm{OAc})_{2}$ を用いた場合に，触媒的な酸化的 転位反応を見い出した (Scheme 5). 3 eq の水は, アセテート体（9e）の副生を防ぐ目的で添加した.

しかしながら, 化学量論量の検討において短時 間・高収率で反応が進行していた 9a でも，10 mol $\%$ と多い触媒量を必要とし，かつ，10\%程度の分解 物を伴うために収率も $85 \%$ に留まった。この原因 は, $\mathrm{PhI}(\mathrm{OAc})_{2}$ 由来の $\mathrm{AcO}^{-}$と塩を形成した 


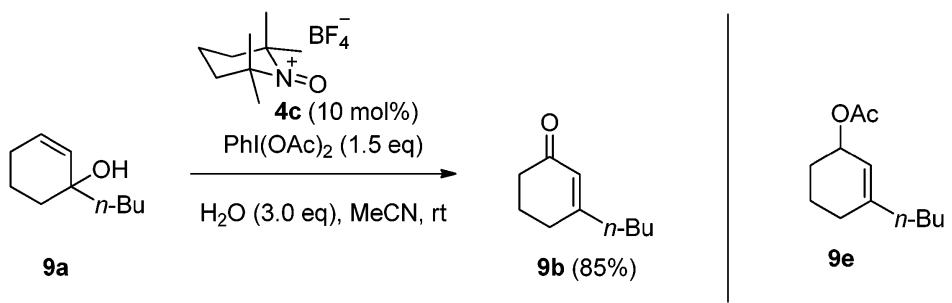

Scheme 5. Catalytic Oxidative Rearrangement Using $\mathrm{TEMPO}^{+} \mathrm{BF}_{4}^{-}(\mathbf{4 c})$ and $\mathrm{PhI}(\mathrm{OAc})_{2}$

Table 3. Optimization of Catalytic Oxidative Rearrangement Using Catalytic TEMPO (1) and $\mathrm{NaIO}_{4}$

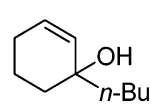

$9 a$

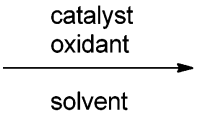

solvent

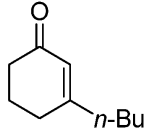

9b

\begin{tabular}{lcccc}
\hline \hline \multicolumn{1}{c}{ Catalyst (mol\%) } & Oxidant (eq) & Solvent & Time $(\mathrm{h})$ & Yield (\%) \\
\hline $\mathrm{TEMPO}(\mathbf{1})(10)$ & $\mathrm{NalO}_{4}(1.5)$ & $\mathrm{CH}_{2} \mathrm{Cl}_{2}-\mathrm{H}_{2} \mathrm{O}$ & 1 & 70 \\
$\mathrm{TEMPO}+\mathrm{BF}_{4}^{-}-(\mathbf{4 a})(5)$ & $\mathrm{NalO}_{4}(1.5)$ & $\mathrm{CH}_{2} \mathrm{Cl}_{2}-\mathrm{H}_{2} \mathrm{O}$ & 1.5 & 85 \\
$\mathrm{TEMPO} \mathrm{BF}_{4}^{-}(\mathbf{4 a})(5)$ & $\mathrm{NalO}_{4}-\mathrm{SiO}_{2}(1.5)$ & $\mathrm{CH}_{2} \mathrm{Cl}_{2}$ & 0.5 & 90 \\
$\mathrm{TEMPO}(\mathbf{1})(1)$ & $\mathrm{NalO}_{4}-\mathrm{SiO}_{2}(2.0)$ & $\mathrm{CH}_{2} \mathrm{Cl}_{2}$ & 2 & 92 \\
\hline
\end{tabular}

$\mathrm{TEMPO}^{+} \mathrm{OAc}^{-}$の発生が競合するためと考察し た。 そこで， $\mathrm{NaIO}_{4}$ を共酸化剂として TEMPO（1) から $\mathrm{TEMPO}^{+} \mathrm{IO}_{\mathrm{x}}^{-}$が発生できれば， $\mathrm{IO}_{\mathrm{x}}^{-}$は高い共 役酸の酸性度と嵩高さを併せ持つカウンターアニオ ンとして機能するのではないかと期待し検討した (Table 3)。その結果，TEMPO（1）と $\mathrm{NaIO}_{4}$ を用 いた条件で酸化的転位反応が中程度の収率で進行し た.さらに条件の最適化を行った結果，シリカゲル に $\mathrm{NaIO}_{4}$ を吸着させた $\mathrm{NaIO}_{4}-\mathrm{SiO}_{2}$ を用いると TEMPO（1）を $1 \mathrm{~mol} \%$ とした条件でも収率よく反 応が進行することを見い出した. ${ }^{35,36)}$

そこで，本条件の基質適用性について検討した (Table 4)。ママクロ環基質，鎖状基質では，触媒量 を $10 \mathrm{~mol} \%$ とする必要があったが，化学量論量の オキソアンモニウム塩を用いた条件と同様に，5,6 員環基質に限定されない広範な基質適用性が明らか となった。ただし，触媒的条件では，末端ビニル 15a の酸化的転位反応は進行しなかった。

以上のように，第 3 級アリルアルコールの酸化的 転位反応の開発過程において, カウンターアニオン がオキソアンモニウムの反応性に大きな影響を与え ていることが明らかとなった．また，カウンターア ニオンを制御することで，触媒化にも成功した.
4. 第 1 級アルコールからカルボン酸へのワンポ ット酸化反応の開発 371

第 1 級アルコールからカルボン酸へのワンポット 酸化反応は，第 1 級アルコールからアルデヒドへの 酸化とアルデヒドからカルボン酸への酸化の 2 段階 をワンポットで進行させることから合成の効率性を 向上させる有用な反応である，古くは，過マンガン 酸，濃硝酸，Jones 酸化などが用いられてきた. 1970 年代以降になると, 精密有機合成の発展に伴 い様々な手法が報告されてきたが，特に，DMF 中 PDC を用いる Corey らにより報告されたワンポッ 卜酸化反応は，マイルドな条件下に反応が進行する ことから現代にいたるまで広く適用されてきた。 ${ }^{38)}$ 近年は，グリーンケミストリーへの関心の高まりか ら, 過酸化水素を用いる触媒的反応や 3 価超原子価 ヨウ素試薬を用いる反応を始め, 多くの環境調和型 酸化反応が開発されるようになってきた. ${ }^{39-41)} し か$ しながら，天然物合成など多官能基化合物への適用 性という観点からは，より効率的なワンポット酸化 反応の開発が求められている.

TEMPO（1）を触媒とするワンポット酸化反応 も，環境調和性や大量スケールへの適用性等の観点 から重要視され，活発な研究が行われている. ${ }^{42-46)}$ そこで，筆者は，TEMPO（1）を用いて報告され 
たワンポット酸化反応条件に，高活性アルコール酸 化触媒 1-Me-AZADO（3）を用いることによって 適用性が拡張できれば，有用な反応となるものと期 待し研究を開始した. ワンポット酸化反応は通常, アルコールからアルデヒドへの酸化，アルデヒドの 水和, gem-ジオールの酸化の 3 つのステップを経 て進行する（Scheme 6)。1-Me-AZADO（3）は， 高い活性を持つため第 1 級アルコールに比べ相対的

Table 4. Scope of Catalytic Oxidative Rearrangement

(1)

Condition: $\operatorname{TEMPO}(\mathbf{1})(1.0 \mathrm{~mol} \%), \mathrm{NalO}_{4}-\mathrm{SiO}_{2}(2.0$ eq. $), \mathrm{CH}_{2} \mathrm{Cl}_{2}$, rt. a The reaction was performed with $10 \mathrm{~mol} \% \operatorname{TEMPO}(\mathbf{1})$ and 4 eq $\mathrm{NalO}_{4}$ on silica gel.
に嵩高い gem-ジオールの酸化も速やかに進行し， TEMPO（1）を用いた場合に比べ適用性が大きく 改善されるものと期待した.

TEMPO 酸化反応において，第 1 級アルコールか らアルデヒドへの酸化反応に用いられる共酸化剂で ある $\mathrm{NaOCl}$ や $\mathrm{PhI}(\mathrm{OAc})_{2}$ は，その添加量を増やす ことによってワンポット酸化反応が進行することが 知られていた. ${ }^{42,43)}$ そこで，これらを共酸化剂とし て検討を開始した。その結果，1-Me-AZADO（3) は，期待通り TEMPO（1）に比べ良好な結果を与 えるものの, ワンポット酸化反応が進行しない基質 も多いことが明らかとなった（Table 5)。特に，芳 香環に電子供与性基を持つベンジルアルコール 21 で低収率であったことから，アルデヒドへの水和が 起こり難いことが 2 段階目の酸化を妨げている原因 ではないかと考察した。

ここで，Merck のZhao らによって報告されてい る TEMPO (1) $/ \mathrm{NaOCl} / \mathrm{NaClO}_{2}$ 条件に着目し た. ${ }^{44,45)}$ この条件では, TEMPO (1) とともに $\mathrm{NaOCl}$ を触媒的に用い， $\mathrm{NaClO}_{2}$ を terminal oxidant とし て, Scheme 7 に示す反応機構で進行するとされて いる.

この反応では，アルデヒドの水和を経ることはな $<$, Kraus-Pinnick 酸化と同様に $\mathrm{ClO}_{2}^{-}$がアルデヒ ドへ直接的に付加して 2 段階目の酸化が進行する. そのため，上記の検討で問題であった水和の段階を 回避できる，しかしながら，Zhao らは，論文中で Fig. 4 に示す基質には適用できないことと $\mathrm{NaOCl}$ と $\mathrm{NaClO}_{2}$ は混合によって爆発的な反応を起こすこ とから，これらは，別々にゆっくりと滴下する必要 があることを述べていた. ${ }^{42,43)}$ 筆者は，高い反応性 を持つ $\mathrm{NaOCl}$ が直接的に基質 $\pi$ 電子と反応してし まうことが適用性に限界を与えている原因と考察し， $\mathrm{NaOCl}$ の使用を回避する条件が開発できれば，基 質適用性が拡張できるものと考えた。さらに， $\mathrm{NaOCl}$ を回避できれば，混合の問題も解決できる. このような考察に基づき，筆者は，1-Me-AZADO+ $\mathrm{Cl}^{-}(\mathbf{6 a})$ 触媒と $\mathrm{NaClO}_{2}$ を用いる酸化システムが,

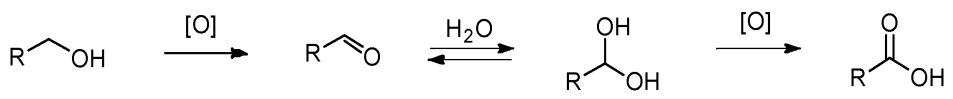

Scheme 6. One-Pot Oxidation of Primary Alcohols to Carboxylic Acids 
Table 5. One-Pot Oxidation Using $\mathrm{NaOCl}$ and $\mathrm{PhI}(\mathrm{OAc})_{2}$

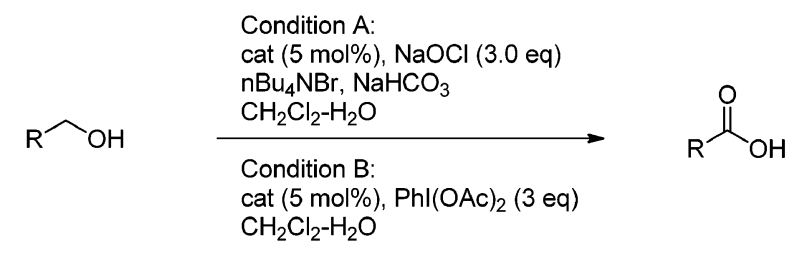

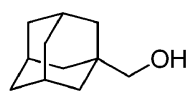

20

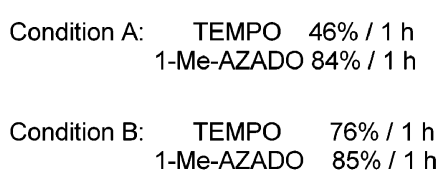
1-Me-AZADO $85 \% / 1 \mathrm{~h}$

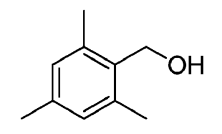

21

TEMPO $<5 \% / 1 \mathrm{~h}$ 1 -Me-AZADO $<5 \% / 1 \mathrm{~h}$ $\begin{array}{cc}\text { TEMPO } & 3 \% / 1 \mathrm{~h} \\ 1-M e-A Z A D O & 8 \% / 1 \mathrm{~h}\end{array}$<smiles>CCCCCC(C)(O)CO</smiles>

22

23<smiles>[Z6]C1CCC(CO)(c2ccccc2)CC1</smiles>

No desired products

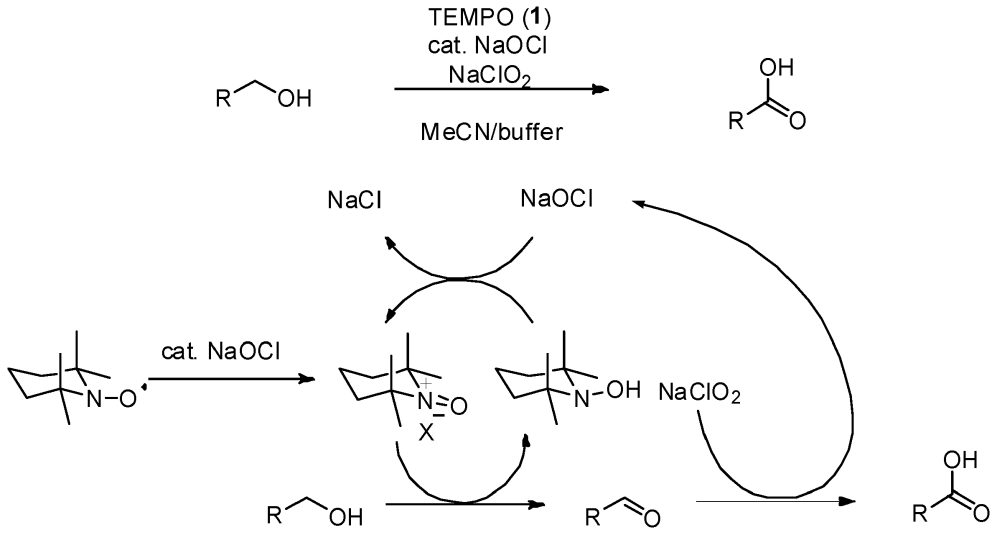

Scheme 7. Reaction Mechanism for One-Pot Oxidation under Merck's Conditions<smiles>COc1ccc(Cl)c(CCO)c1</smiles>

26<smiles>OC/C=C/c1ccccc1</smiles>

22<smiles>COc1ccc(CCO)cc1OC</smiles>

27<smiles>OCc1ccco1</smiles>

28<smiles>COc1ccc(CO)cc1</smiles>

29

Fig. 4. The Reported Alcohols Inapplicable to Merck’s Oxidation

上記の問題点を解決すると期待した (Scheme 8). すなわち，Zhao らの条件において $\mathrm{NaOCl}$ は，反 応開始時にニトロキシルラジカルをオキソアンモニ ウムへと酸化するために用いられている。 したがつ て，オキソアンモニウム塩を触媒として添加する場 合には, $\mathrm{NaOCl}$ は不要となる，また，TEMPO（1) の代わりに 1-Me-AZADO（3）を用いることで, 第 1 級アルコールからアルデヒドへの酸化がより速 やかに起こるのみならず，1-Me-AZADOH は，
$\mathrm{NaClO}_{2}$ によるアルデヒドからカルボン酸への酸化 により生じる $\mathrm{NaOCl}$ とより速やかに反応して，才 キソアンモニウム塩を再生するものと期待した。

1-Me-AZADO ${ }^{+} \mathrm{Cl}^{-}\left(\right.$6a) 及び 1-Me-AZADO ${ }^{+} \mathrm{BF}_{4}^{-}$ (6c) を調製し, $\mathrm{TEMPO}^{+} \mathrm{Cl}^{-}(\mathbf{4 a}), \mathrm{TEMPO}^{+} \mathrm{BF}_{4}^{-}$ （4c）と比較条件下, 検討を行つた. ${ }^{29)}$ その結果, 塩濃度の高い緩衝液の使用が再現性よくワンポット 酸化を進行させるために重要であることが分かった が，様々な第 1 級アルコール基質において効率的に 


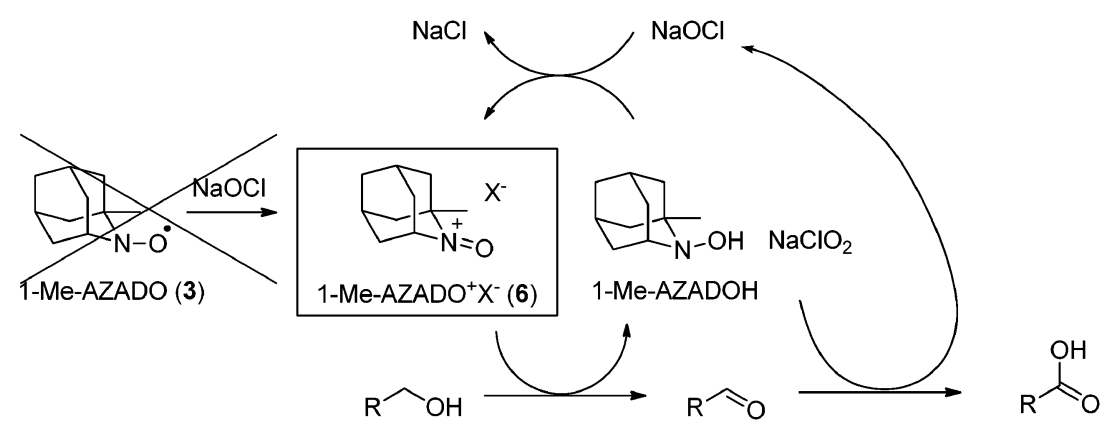

Scheme 8. Reaction Mechanism of 1-Me-AZADO ${ }^{+} \mathrm{Cl}^{-}(\mathbf{6 c}) / \mathrm{NaClO}_{2}$ Oxidation

Table 6. Scope of One-Pot Oxidation Using Catalytic Oxoammonium Salt $/ \mathrm{NaClO}_{2}$

$$
\stackrel{\mathrm{R}}{\stackrel{\substack{\text { oxoammnoium salt }(5 \mathrm{~mol} \%) \\ \mathrm{NaClO}_{2}(3 \mathrm{eq})}}{\substack{\text { phosphate buffer }(1.0 \mathrm{M}, \mathrm{pH} 6.8) \\ \mathrm{MeCN}}}}
$$

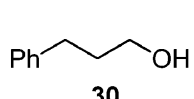

30

$98 \% / 30 \mathrm{~min}$ $98 \% / 1.5 \mathrm{~h}$ $98 \% / 30 \mathrm{~min}$ $93 \% / 30 \mathrm{~min}$<smiles>OCC1(c2ccccc2)CCCCC1</smiles>

$79 \% / 10 \mathrm{~h}$ $97 \% / 10 \mathrm{~h}$ $93 \% / 10 \mathrm{~h}$ $97 \% / 10 \mathrm{~h}$<smiles>Cc1cc(C)c(CO)c(C)c1</smiles>

$100 \% / 9.5 \mathrm{~h}$ $83 \% / 8 \mathrm{~h}$ $98 \% / 7 \mathrm{~h}$ $98 \% / 7 \mathrm{~h}$<smiles>OC/C=C/c1ccccc1</smiles>

31

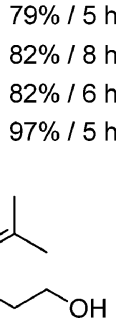

33

$<10 \% / 48 \mathrm{~h}$ $<10 \% / 48 \mathrm{~h}$ $73 \% / 24 \mathrm{~h}$ $78 \% / 18 \mathrm{~h}$<smiles>COc1ccc(CO)cc1</smiles>

$92 \% / 40 \mathrm{~h}$ $96 \% / 40 \mathrm{~h}$ $92 \% / 23.5 \mathrm{~h}$ $97 \%$ / $26 \mathrm{~h}$<smiles>COc1ccc(CCO)cc1OC</smiles>

27 $\mathrm{TEMPO}^{+} \mathrm{BF}_{4}^{-}(4 \mathrm{c})$ 1-Me-AZADO+ ${ }^{+} \mathrm{Cl}^{-}(\mathbf{6 a})$ 1-Me-AZADO ${ }^{+} \mathrm{BF}_{4}^{-}(6 \mathrm{c})$<smiles>CCCCCC(C)(O)CO</smiles>

$93 \% / 9.5 \mathrm{~h}$

$92 \% / 30 \mathrm{~min}$<smiles>O=C(NC(CO)CO)OCc1ccccc1</smiles>

34

$13 \% 42 \mathrm{~h}$ $8 \% / 42 \mathrm{~h}$ $100 \% / 18 \mathrm{~h}$ $94 \%$ / $24 \mathrm{~h}$
ワンポット酸化反応が進行することを見い出した (注意 : 低塩濃度の緩衝液では, 反応が暴走するこ とがある）（Table 6）。興味深いことに，Zhao らの 方法では適用できないとされていたアニシルアル コール 32 の酸化は，1-Me-AZADO ${ }^{+} \mathrm{X}^{-}$（6）だけ でなく $\mathrm{TEMPO}^{+} \mathrm{X}^{-}$（4）を用いた場合にも収率よ く反応は進行した。ジメトキシフェニルエタノール 27 では, $\mathrm{TEMPO}^{+} \mathrm{Cl}^{-}$(4a) を用いた場合には, ベンジル位で酸化的開裂が進行した副生成物が伴う のに対し，1-Me-AZADO+ $\mathrm{Cl}^{-}$（6a）を用いた場合 には，酸化的な開裂が進行することなく収率よく反 応が進行した。 プレニル基を持つアルコール 33 で は， $\mathrm{TEMPO}^{+} \mathrm{X}^{-}(\mathbf{4})$ を用いた場合には，ほとん ぞ反応が進行しなかったが，1-Me-AZADO ${ }^{+} \mathrm{X}^{-}(\mathbf{6})$
を用いた場合には高収率で目的のカルボン酸が得ら れた。この際，1-Me-AZADO+ ${ }^{+}{ }^{-}$（6a）を用いた 場合には，18\%の塩素化体が副生したが，1-Me$\mathrm{AZADO}^{+} \mathrm{BF}_{4}^{-}$(6c) を用いた場合には，塩素化体の 副生は，3\%と優位に抑制された。ささに，アミノ アルコール 34 の酸化においても, 1-Me-AZADO ${ }^{+} \mathrm{X}^{-}$ （6）を用いると，ラセミ化を伴うことなく効率的に ワンポット酸化が進行した.

シンナミルアルコール（31）を $5 \mathrm{~g}$ ，ジメトキシ フェニルエタノール 27 を $10 \mathrm{~g}$ 用いて大量スケール への適用性を検討したが，この場合にも反応は収率 よく進行した（Scheme 9).

以上のように，ニトロキシルラジカルではなくオ キソアンモニウム塩である $1-\mathrm{Me}-\mathrm{AZADO}^{+} \mathrm{X}^{-}{ }^{-}(\mathbf{6})$ 


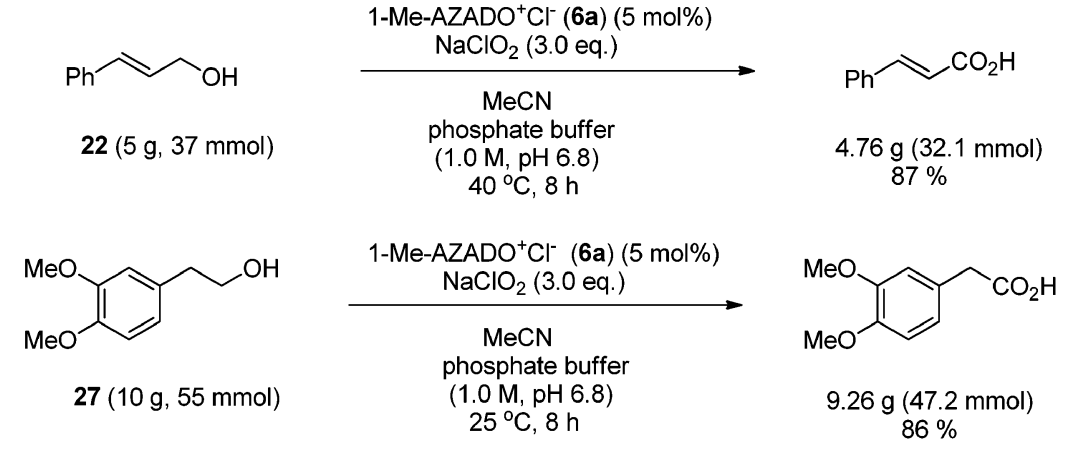

Scheme 9. Application to Large-Scale Oxidations

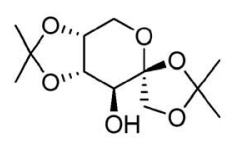

$22 \mathrm{a}(26.0 \mathrm{~g})$

$0.1 \mathrm{~mol}$

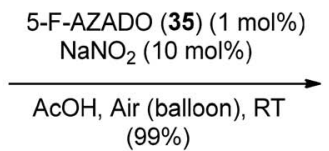

$(99 \%)$

Scheme 10. Aerobic Alcohol Oxidation Using 5-F-AZADO (35) and $\mathrm{NaNO}_{2}$

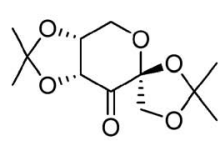

$22 \mathrm{~b}(25.6 \mathrm{~g})$
を触媒として用いた新規触媒システムの構築によつ て，これまで副反応を起こす原因となっていた $\mathrm{NaOCl}$ の使用の回避に成功した。これにより，基 質適用性に優れたワンポット酸化反応を開発した.

\section{5. 空気酸化反応の開発47)}

分子状酸素を terminal oxidant とする触媒的酸化 反応は，水のみを副生物とする理想的なアルコール 酸化反応プロセスを実現する. 常温, 常圧で空気中 の分子状酸素を用いて効率的なアルコール酸化反応 プロセスが開発できれば，最も理想的である。この ような観点から，これまで活発な研究が展開され数 多くの触媒的空気酸化反応の報告がなされてき た. ${ }^{48-50)}$ しかしながら，天然物合成などの多官能基 化合物への適用例はいまだごく限られており，基質 適用性，効率性により優れた手法の開発が望まれて いる．筆者らは， Hu と Liangによって開発された TEMPO（1）による空気酸化条件を基に，効率的 アルコール空気酸化反応の開発を目指し検討を行っ た. ${ }^{51-54)}$ その結果，AZADOの 5 位にフッ素原子を 導入した 5-F-AZADO (35) と $\mathrm{NaNO}_{2}$ を用いると, 常圧常温で遷移金属フリー，ハロゲンフリーの条件 下効率的にアルコールの空気酸化反応が進行するこ とを見い出した. ${ }^{47)}$ 本反応は， $0.1 \mathrm{~mol}$ スケールの アルコール酸化反応も常温常圧下で効率的に進行す る (Scheme 10).
上記反応の開発過程において, 反応機構解明のた めに触媒活性種となるオキソアンモニウム塩の単離 を試みたところ 5-F-AZADO ${ }^{+} \mathrm{NO}_{3}^{-}$（36）の単離に

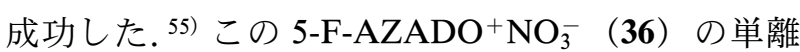
は，本空気酸化反応条件においてオキソアンモニウ ム種が発生し酸化が進行していることを示す重要な 結果であったが，同時に，この 5-F-AZADO ${ }^{+} \mathrm{NO}_{3}^{-}$ （36）は，5-F-AZADO（35） と $\mathrm{NO}_{\mathrm{x}}$ 部を併せ持つ ために，単一の触媒で両者の働きを果たすバイファ ンクショナルな触媒としても機能する可能性を示し ていた（Fig. 5).

そこで，5-F-AZADO ${ }^{+} \mathrm{NO}_{3}^{-}$（36） $5 \mathrm{~mol} \%$ を触媒 として添加し，空気酸化反応を検討したところ, $\mathrm{NO}_{3}^{-}$部が $\mathrm{NaNO}_{2}$ と同様に共触媒として機能し, 速やかに空気酸化反応が進行することを見い出し た．そこで，様々な基質を本反応条件に付したとこ ろ，幅広い基質において，短時間・高収率で対応す るカルボニル化合物が得られた（Table 7)。三置換 オレフィン 43 では，エン型反応による付加体 $\mathbf{4 4}$ が 得られ酸化は進行しなかったが，アミノアルコール 34 でもラセミ化を起こすことなく目的のアルデヒ ドが得られた。

5-F-AZADO ${ }^{+} \mathrm{NO}_{3}^{-}$（36）は，検討の結果，5-FAZADO（35）をジエチルエーテル溶液として酸素 雾囲気下 $\mathrm{HNO}_{3}$ を添加することにより調製できる 


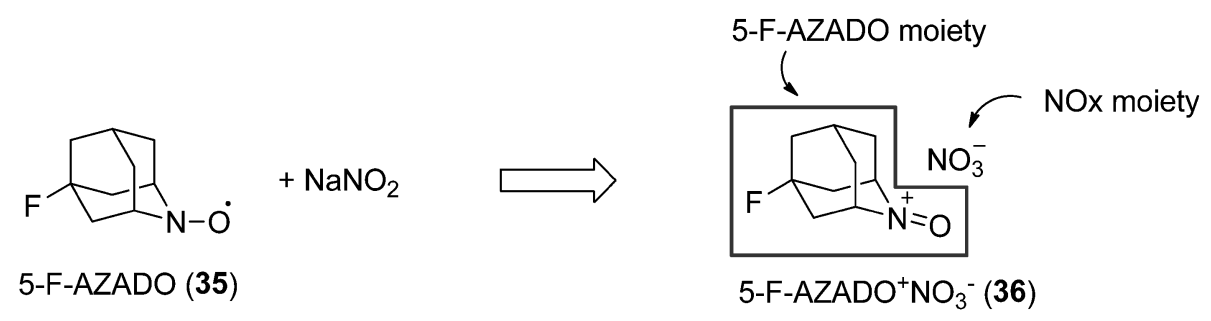

Fig. 5. Structural Analysis of 5-F-AZADO ${ }^{+} \mathrm{NO}_{3}^{-}$(36)

Table 7. Scope of 5-F-AZADO ${ }^{+} \mathrm{NO}_{3}^{-}$(36) Catalyzed Aerobic Oxidation

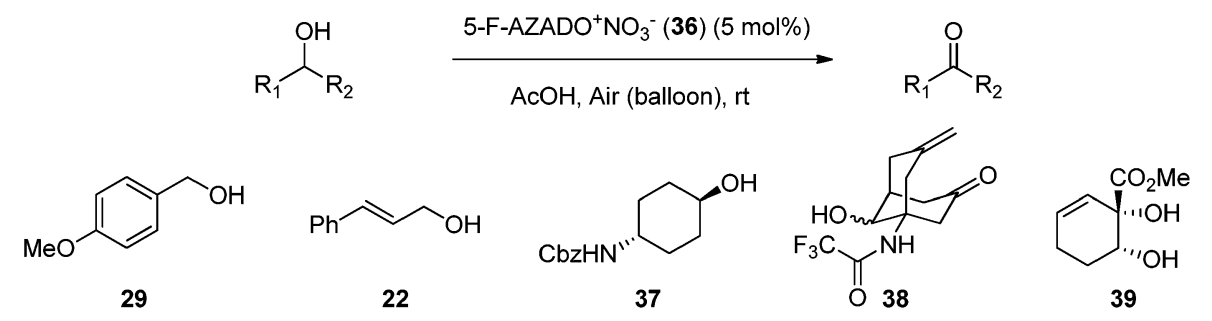

$96 \% / 0.75 \mathrm{~h}$

$79 \% / 10 \mathrm{~h}$

$99 \% / 1.5 \mathrm{~h}$

$96 \% / 2 \mathrm{~h}$

$96 \% / 0.5 \mathrm{~h}$

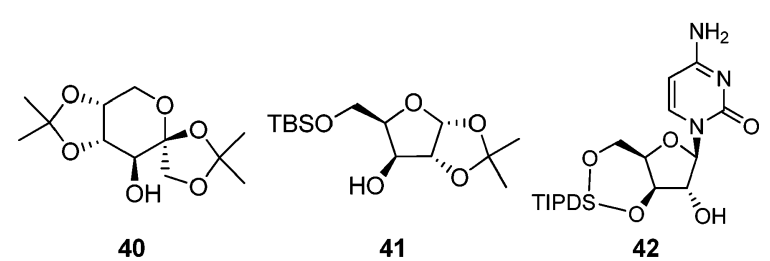

$97 \% / 0.5 \mathrm{~h}$

$91 \% / 0.5 \mathrm{~h}$

$90 \% / 0.5 \mathrm{~h}^{\mathrm{a}}$

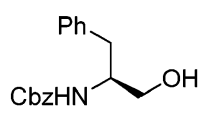

34

$71 \% / 5 \mathrm{~h}^{\mathrm{b}}$

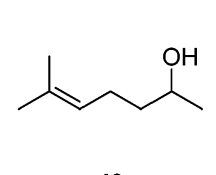

43

$0 \% / 1.5 \mathrm{~h}$

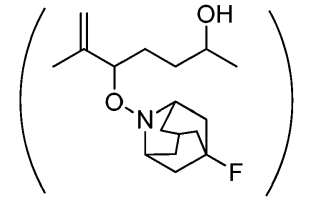

44

a 5 mol\% $\mathrm{NaNO}_{2}$ was added. ${ }^{\mathrm{b}} \mathrm{AcOH}$ (10 equiv.) and $\mathrm{MeCN}$ solvent was used instead of $\mathrm{AcOH}$ solvent.

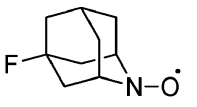

5-F-AZADO (35)

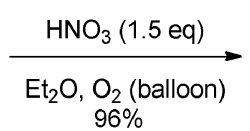
$96 \%$

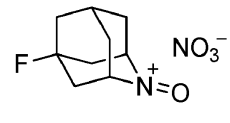

$5-\mathrm{F}-\mathrm{AZADO}^{+} \mathrm{NO}_{3}^{-}(36)$
Scheme 11. Simple Preparation of 5-F-AZADO ${ }^{+} \mathrm{NO}_{3}^{-}(36)$

ことが明らかとなった (Scheme 11)。5-F-AZADO+ $\mathrm{NO}_{3}^{-}$（36）は，この条件下に析出するため，ろ取 により簡便に単離することができる.

本条件では, 反応終了後 30 分間擋汼し過剰量のジ エチルエーテルを加えると, 触媒 5-F-AZADO ${ }^{+} \mathrm{NO}_{3}^{-}$ （36）が析出し，72\%の収率で回収が可能であった (Scheme 12)。前述の 5-F-AZADO (35) と $\mathrm{NaNO}_{2}$ を用いる条件では, 同様の処理では触媒の回収はで きずメタルフリーの 5-F-AZADO ${ }^{+} \mathrm{NO}_{3}^{-}$（36）を用 いる条件で初めて可能となつた。

\section{6. おわりに}

以上述べてきたように, 化学量論量オキソアンモ ニウム塩を用いた第 3 級アリルアルコールの酸化的
転位反応において，カウンターアニオンが反応性に 大きな影響を与えていることが明らかとなつた。こ の発見を契機として，筆者は，オキソアンモニウム 塩とニトロキシルラジカルとの違いである酸化段階 とカウンターアニオンに着目して酸化反応システム の開発を行った。その結果, 系中で発生するオキソ アンモニウム種のカウンターアニオンを制御するこ とによって触媒的な第 3 級アリルアルコールの酸化 的転位反応の開発に成功した。 また, 酸化段階の違 いを利用したオキソアンモニウム塩触媒システムの 開発により基質適用性の広い第 1 級アルコールから カルボン酸へのワンポット酸化反応の開発に成功し た.さらに, カウンターアニオンを $\mathrm{NO}_{\mathrm{x}}$ ソースと して利用しバイファンクショナルなオキソアンモニ ウム塩触媒 5-F-AZADO ${ }^{+} \mathrm{NO}_{3}^{-}$(36) とすることで, 単一の有機触媒のみを用いた常圧・常温でのアル コールの空気酸化反応を見い出した。ここで得られ た研究成果が，適用性に優れた酸化手法として創薬 研究の場で広く使用されることを期待している。 


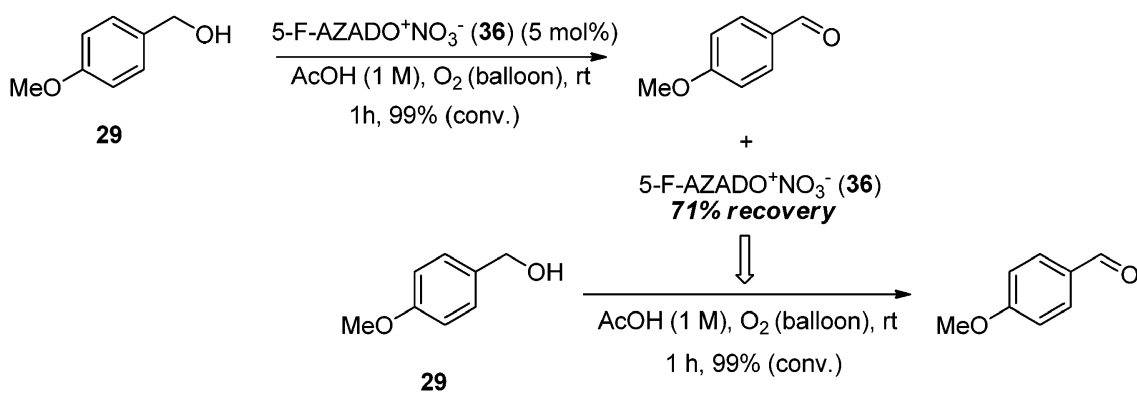

Scheme 12. Recycling of 5-F-AZADO ${ }^{+} \mathrm{NO}_{3}^{-} \quad(36)$

謝辞本研究は, 筆者が東北大学大学院薬学研 究科在籍中に岩渕好治教授のご指導の下行つたもの であり，この場を借りて厚く御礼申し上げます。こ こで紹介した研究成果は，共同研究者の日々の努力 によって得られたものであり，ここに感謝いたしま す。また, 本研究の一部は, 文部科学省科学研究費 補助金の援助により行われたものであり，併せて御 礼申し上げます。

\section{REFERENCES}

1) de Nooy A. E. J., Besemer A. C., van Bekkum H., Synthesis, 1153-1174 (1996).

2) Bobbitt J. M., Brockner C., Merbouh N., Org. React., 74, 103-424 (2009).

3) Studer A., Tebben L., Angew. Chem. Int. Ed., 50, 5034-5068 (2011).

4) Dugger R. W., Ragan J. A., Ripin D. H. B., Org. Process Res. Dev., 9, 253-258 (2005).

5) Shibuya M., Tomizawa M., Suzuki I., Iwabuchi Y., J. Am. Chem. Soc., 128, 8412-8413 (2006).

6) Bowman D. F., Gillan T., Ingold K. U., J. Am. Chem. Soc., 93, 6555-6561 (1971).

7) Martinie J., Rassat A., Tetrahedron, 30, 433436 (1974).

8) Dupeyre R. M., Rassat A., Tetrahedron, 34, 1501-1507 (1978) .

9) Shibuya M., Tomizawa M., Sasano Y., Iwabuchi Y., J. Org. Chem., 74, 4619-4622 (2009) .

10) Hayashi M., Sasano Y., Nagasawa S., Shibuya M., Iwabuchi Y., Chem. Pharm. Bull., 59, 1570-1573 (2011).

11) Golubev V. A., Borislavskii V. N., Aleksandrov A. L., Acad. Sci. USSR Div. Chem. Sci., 26, 1874-1881 (1977).
12) Semmelhack M. F., Schmid C. R., Cortes D. A., Tetrahedron Lett., 27, 1119-1122 (1986).

13) Ma Z., Bobbitt J. M., J. Org. Chem., 56, 6110 -6114 (1991).

14) Bailey W. F., Bobbitt J. M., Wiberg K. B., $J$. Org. Chem., 72, 4504-4509 (2007) .

15) Shibuya M., Tomizawa M., Iwabuchi Y., $J$. Org. Chem., 73, 4750-4752 (2008).

16) Babler J. H., Coghlan M. J. Synth. Commun., 6, 469-474 (1976).

17) Dauben W. G., Michno D. M., J. Org. Chem., 42, 682-685 (1977).

18) Sundararaman P., Herz W., J. Org. Chem., 42, 813-819 (1977).

19) Shibuya M., Ito S., Takahashi M., Iwabuchi Y., Org. Lett., 6, 4303-4306 (2004).

20) Anelli P. L., Biffi C., Montanari F., Quici S., J. Org. Chem., 52, 2559-2562 (1987).

21) DeMico A., Margarita R., Parlanti L., Vescovi A., Piancatelli G., J. Org. Chem., 62, 69746977 (1997).

22) Bolm C., Magnus A. S., Hildebrand J. P., Org. Lett., 2, 1173-1175 (2000) .

23) De Luca L., Giacomelli G., Porcheddu A., Org. Lett., 3, 3041-3043 (2001).

24) Miller R. A., Hoerrner R. S., Org. Lett., 5, 285-287 (2003).

25) Bobbitt J. M., Flores M. C. L., Heterocycles, 27, 509-533 (1988).

26) Golubev V. A., Rozantsev E. G., Neiman M. B., Bull. Acad. Sci. USSR Div. Chem. Sci., 1898-1904. (1965).

27) Golubev V. A., Zhdanov R. I., Rozantsev E. G., Bull. Acad. Sci. USSR Div. Chem. Sci., 186-187 (1970).

28) Golubev V. A., Zhdanov R. I., Gida V. M., Rozantsev E. G., Bull. Acad. Sci. USSR Div. 
Chem. Sci., 768-770 (1971).

29) Bobbitt J. M., J. Org. Chem., 63, 9367-9374 (1998).

30) Pradhan P. P., Bobbitt J. M., Bailey W. F., Org. Lett., 8, 5485-5487 (2006).

31) Biffis A., Gazzola L., Gobbo P., Buscemi G., Tubaro C., Basato M., Eur. J. Org. Chem., 3189-3198 (2009).

32) Kütt A., Rodima T., Saame J., Raamat E., Mäemets V., Kaljurand I., Koppel I. A., Garlyauskayte R. Y., Yagupolskii Y. L., Yagupolskii L. M., Bernhardt E., Willner H., Leito I., J. Org. Chem., 76, 391-395 (2011).

33) Olah G. A., J. Org. Chem., 70, 2413-2429 (2005).

34) Shibuya M., Tomizawa M., Iwabuchi Y., Org. Lett., 10, 4715-4718 (2008).

35) Daumas M., Vo-Quang Y., Vo-Quang L., Le Goffic F., Synthesis, 64-65 (1989).

36) Zhong Y.-L, Shing T. K. M., J. Org. Chem., 62, 2622-2624 (1997).

37) Shibuya M., Sato T., Tomizawa M., Iwabuchi Y., Chem. Commun., 1739-1741 (2009).

38) Corey E. J., Schmidt G., Tetrahedron Lett., 20, 399-402 (1979).

39) Sato K., Aoki M., Takagi J., Noyori R., J. Am. Chem. Soc., 119, 12386-12387 (1997).

40) Tohma H., Takizawa S., Maegawa T., Kita Y., Angew. Chem. Int. Ed., 39, 1306-1308 (2000) .

41) Mazitschek R., Mulbaier M., Giannis A., Angew. Chem. Int. Ed., 41, 4059-4061 (2002).

42) Anelli P. L., Biffi C., Montanari F., Quici S.,
J. Org. Chem., 52, 2559-2562 (1987).

43) Epp J. B., Widlanski T. S., J. Org. Chem., 64, 293-295 (1999).

44) Zhao M. Z., Li J., Mano E., Song Z. G., Tschaen D. M., Grabowski E. J. J., Reider P. J., J. Org. Chem., 64, 2564-2566 (1999) .

45) Zhao M. M., Li J., Mano E., Song Z. J., Tschaen D. M., Org. Synth., 81, 195-203 (2005).

46) Zanka A., Chem. Pharm. Bull., 51, 888-889 (2003).

47) Shibuya M., Osada Y., Sasano Y., Tomizawa M., Iwabuchi Y., J. Am. Chem. Soc., 133, 6497-6500 (2011).

48) Sigman M. S., Schultz M. J., Tetrahedron, 62, 8227-8241 (2006).

49) Marko I. E., Giles P. R., Tsukazaki M., Brown S. M., Urch C. J., Science, 274, 20442046 (1996).

50) ten Brink G., Arends I. W. C. E., Sheldon R. A., Science, 287, 1636-1639 (2000) .

51) Liu R. H., Liang X. M., Dong C. Y., Hu X. Q., J. Am. Chem. Soc., 126, 4112-4113 (2004) .

52) Wang N., Liu R., Chen J., Liang X., Chem. Commun., 5322-5324 (2005).

53) Wang X., Liu R., Jin Y., Liang X., Chem. Eur. J., 14, 2679-2685 (2008).

54) He X. J., Shen Z. L., Mo W. M., Sun N., Hu B. X., Hu X. Q., Adv. Synth. Catal., 351, 8992 (2009).

55） Chou S., Nelson J. A., Spencer T. A., J. Org. Chem., 39, 2356-2361 (1974). 